\title{
REZIM HAK KEPEMILIKAN DAN AKSES TERHADAP SUMBERDAYA LAHAN BAGI EFEKTIVITAS INSTITUSI PENGELOLAAN KAWASAN KONSERVASI PENYU ${ }^{1}$
}

\author{
Tjahjo Tri Hartono 2 , Hariadi Kartodihardjo 3 , Ari Purbayanto, Arif Satria ${ }^{4}$ \\ ${ }^{2}$ Balai Besar Penelitian Sosial Ekonomi Kelautan dan Perikanan \\ JI. KS. Tubun Petamburan VI Jakarta 10260 \\ Telp. (021) 53650162, Fax. (021)53650159 \\ ${ }^{3}$ Ketua Komisi Pembimbing \\ ${ }^{4}$ Anggota Komisi Pembimbing \\ Email: tjahjo3@gmail.com
}

Diterima 25 Juni 2012 - Disetujui 3 Desember 2012

\begin{abstract}
ABSTRAK
Penelitian ini bertujuan untuk merancang sebuah rezim hak kepemilikan tanah dan hak terhadap akses pengelolaan yang mendukung lembaga konservasi penyu yang efektif. Penelitian ini dilakukan di Ujung Genteng - Pangumbahan, Kabupaten Sukabumi sebagai daerah pesisir yang terkait dengan upaya konservasi penyu mulai dari bulan Desember 2009 sampai Maret 2012. Data yang dikumpulkan dianalisis dengan menggunakan metode analisis spasial dan analisis deskriptif. Hasil penelitian dengan menggunakan analisis spasial pada wilayah seluas 1.334,70 hektar menunjukkan bahwa antara tahun 2001 - 2010, luas lahan pertanian meningkat sebesar $31 \%$ dan daerah pengembangannya $(28,78 \%)$ memanjang ke arah pantai. Pola perubahan penggunaan lahan dipicu oleh transisi dari tanah terlantar menjadi pemukiman dan pembangunan fasilitas wisata bahari. Berdasarkan dinamika perubahan penggunaan sumber daya lahan sangat diperlukan perubahan kelembagaan untuk menjamin kepastian pemanfaatan sumberdaya lahan di wilayah pesisir sejalan dengan tujuan konservasi penyu. Pemerintah pusat mendelegasikan otoritas kewenangannya ke tingkat desa dan pemerintah desa menjadi pemilik dan pengelola di instansi yang bersangkutan.
\end{abstract}

Kata Kunci: hak milik, hak akses, sumber daya pesisir dan lahan, lembaga, konservasi penyu laut

\section{Abstract: Property Rights And Access Rights of Land For Turtle Conservation Institutions Effectiveness by Tjahjo Tri Hartono, Hariadi Kartodihardjo, Ari Purbayanto, Arif Satria.}

This research aims to design a regime of rights ownership of land and management access rights that supports the institution of effective sea turtle conservation. This study was conducted at the Ujung Genteng - Pangumbahan, Sukabumi district as coastal areas associated with the sea turtle conservation efforts, startied from the month of December 2009 to March 2012. Data were analyzed using methods of spatial analysis and descriptive analysis. Results of the spatial analysis research area covering of 1,334.70 hectares showed that between the years 2001 to 2010 the agricultural land area increased by 31\% by which it's area development has been (28.78\%) extended towards the coast. Patterns of land use changes were triggered by the transition from land abandoned to seitlement and development of marine tourism facilities. Due to the dynamic change of land utilization, is necessary to change institutional setting in order to ensure the certainty of land resources utilization in the coastal region in line with the ultimate goal of turtle conservation. Central government should delegate his authority to the village level and the villagers are pleased to become the owner and manager in the institution autority.

Keywords: property rights, access rights, coastal and land resources, institutions, sea turtle conservation.

${ }^{1}$ Makalah bagian dari penelitian disertasi. 


\section{PENDAHULUAN}

Salah satu wilayah strategis terkait dengan upaya pelestarian keanekaragaman hayati laut di Indonesia adalah wilayah pesisir Ujung Genteng - Pangumbahan di Kecamatan Ciracap, Kabupaten Sukabumi. Beberapa pertimbangan yang melandasi adalah karena wilayah ini memiliki pantai peneluran penyu hijau (Chelonia mydas) ${ }^{5}$ dan merupakan salah satu dari tiga lokasi di Indonesia dan 30 lokasi lainnya yang tersebar di seluruh dunia yang menjadi indeks lokasi pengamatan kondisi populasi penyu hijau (IUCN 2004). Sementara, banyak ilmuwan meyakini penyu berdasarkan siklus hidupnya berperan penting didalam membawa hara dari habitat laut yang berproduktivitas sangat tinggi seperti padang lamun ke habitat dengan produktivitas rendah seperti pantai berpasir (Frazer 2003).

Menyikapi pentingnya pelestarian keanekaragaman hayati tersebut, Bupati Sukabumi telah menerbitkan SK No: 523/ Kep.639-Dislutkan/2008 tentang Pencadangan Kawasan Penyu Pantai Pangumbahan sebagai Kawasan Konservasi Pesisir dan Pulau-Pulau Kecil (KKP3K) Kabupaten Sukabumi dengan Status "Taman Pesisir" dengan institusi pengelolaan berdasarkan Peraturan Daerah Kabupaten Sukabumi No. 2 Tahun 2009 Tentang Pelestarian Penyu di Kabupaten Sukabumi.

Adanya kebijakan konservasi penyu, terkait perlindungan dan pelestarian pantai peneluran penyu, tentunya akan merubah rejim hak kepemilikan dan hak akses sumberdaya lahan di wilayah pesisir tersebut. Kebijakan konservasi penyu seyogyanya mengarahkan pembentukan institusi yang dapat mengantisipasi perubahan rejim tersebut dan selanjutnya dioperasionalkan oleh aktor-aktor yang bersedia berperilaku rasional dan mereduksi akses ilegal terhadap manfaat barang dan/atau jasa dari sumberdaya lahan di wilayah tersebut, yang bertentangan dengan tujuan kebijakan konservasi penyu itu sendiri (Abarkeli 2001; Scott 2001; Ribbot dan Peluso 2003; Gerber et al 2009). Karenanya, dibutuhkan sebuah penelitian yang memiliki tujuan sebagai berikut: a) Merumuskan rejim hak kepemilikan dan hak akses sumberdaya lahan di wilayah pesisir yang terkait dengan tujuan konservasi penyu; b) Merumuskan perubahan dan efektivitas rejim hak kepemilikan dan hak akses sumberdaya lahan dimaksud berdasarkan kebijakan dan regulasi konservasi penyu yang diterapkan; c) Merumuskan institusi pengelolaan kawasan konservasi penyu yang dapat mengantisipasi perubahan rejim hak kepemilikan dan hak akses sumberdaya lahan yang sesuai dengan tujuan konservasi penyu.

\section{METODOLOGI}

Penelitian dilaksanakan di Desa Ujung Genteng dan Desa Pangumbahan, Kecamatan Ciracap, Kabupaten Sukabumi Provinsi Jawa Barat. Penelitian difokuskan pada daratan pesisir dengan topografi yang relatif sama untuk mengurangi bias terhadap pola penggunaan lahan, khususnya di bidang pertanian (Gambar 1). Penelitian dilaksanakan sepanjang Februari 2009 - Juni 2012 untuk mendapatkan gambaran perubahan rejim hak kepemilikan dan hak akses sumberdaya lahan di lokasi penelitian sesudah kebijakan konservasi penyu diimplementasikan.

Data sekunder dikumpulkan melalui penelusuran literatur di beberapa lembaga pemerintah atau penelitian meliputi data kependudukan (BPS Kabupaten Sukabumi), peta jaringan jalan dan sungai, peta topografi, dan peta penutupan lahan hasil klasifikasi citra landsat ETM+5 tahun 2001 dan 2010.

\footnotetext{
${ }^{5}$ Penyu hijau termasuk dalam 6 jenis penyu yang dilindungi berdasarkan Peraturan Pemerintah No.7/1999 tentang Pengawetan Tumbuhan dan Satwa. Dalam kaitan dengan pengawasan internasional, semua jenis penyu dikategorikan sebagai satwa langka dan dilindungi dalam Red Data Book IUCN dan seluruh jenis penyu sudah termasuk dalam Apendix I CITES (konvensi internsional untuk perdagangan spesies flora dan fauna liar yang terancam kepunahan) atau tergolong jenis satwa yang terancam bahaya kepunahan dan pengaturan perdagangannya mengacu pada prosedur CITES
} 
Data primer diperoleh melalui wawancara mendalam dengan para informan yang terlibat dalam pemanfaatan dan pengelolaan sumberdaya alam serta observasi terhadap berbagai obyek pengamatan sebelum dan sesudah institusi pengelolaan kawasan konservasi diterapkan (tahun 2009 - 2012). Pengambilan data primer juga dilakukan melalui penandaan lokasi atau sejumlah titik untuk mengidentifikasi dan mengklasifikasi sebaran penggunaan dengan menggunakan bantuan Citra Satelit (landsat).

Data dianalisis menggunakan metode analisis spasial dan metode analisis kualitatif deskriptif (Emzir 2010). Metode analisis spasial berupa: (a) analisis pola penggunaan lahan hasil interpretasi/klasifikasi citra satelit tahun 2001 dan tahun 2010 sebagai dasar perhitungan perubahan guna lahan; dan (b) Metode Peramalan (forecasting), yaitu metode analisis yang dipakai untuk memperkirakan perkembangan (trend) yang terjadi di masa depan terhadap perubahan guna lahan tanpa adanya maupun adanya perlakuan (penerapan kebijakan konservasi penyu). Metode ini menggunakan beberapa parameter data spasial berupa: lokasi pemukiman eksisting, jalan, sungai, batas pantai, dan kondisi tutupan/penggunaan lahan tahun 2010.
Masing-masing parameter diukur pengaruhnya terhadap faktor kebutuhan lahan terbangun di masa yang akan datang menggunakan metode skoring atau pembobotan menurut karakteristik dan trend perubahan lahan tahun 2001-2010. Hasil analisis spasial ini ditegaskan oleh hasil analisis kualitatif model Spreadley (Emzir 2010) yang dalam bentuk tabulasi menjelaskan rejim hak kepemilikan dan hak akses sumberdaya lahan berikut perubahannya di wilayah pesisir yang diteliti.

\section{HASIL DAN PEMBAHASAN}

Pola Penggunaan Sumberdaya Lahan Sebelum dan Sesudah Institusi Pengelolaan Kawasan Konservasi Penyu Ditetapkan

Hasil klasifikasi citra landsat pada rentang periode 2001 - 2010 menunjukkan penggunaan lahan sebagian besar untuk pertanian dan lahan terbangun (Tabel 1 dan Gambar 1a dan 1b). Perubahan signifikan pada periode ini adalah meningkatnya luasan lahan pertanian terlantar dan luasan lahan terbangun. Peningkatan luasan lahan pertanian terlantar maupun lahan terbangun berasal dari lahan pertanian (Tabel 2) dan mengarah ke wilayah pantai (Gambar 2).

Tabel 1. Pola Penggunaan Lahan di Wilayah Pesisir Ujung Genteng - Pangumbahan, Periode Tahun 2001 - 2010.

Table 1. Land Used Pattern in Coastal Area of Ujung Genteng-Pangumbahan, Year 2001-2010.

\begin{tabular}{|c|c|c|c|c|c|c|c|}
\hline \multirow[t]{2}{*}{ No } & \multirow{2}{*}{$\begin{array}{l}\text { Penggunaan Lahan/ } \\
\text { Land Used }\end{array}$} & \multicolumn{2}{|c|}{$\begin{array}{c}\text { Tahun/ } \\
\text { Year2001 }\end{array}$} & \multicolumn{2}{|c|}{ Tahun/Year 2010} & \multirow{2}{*}{$\begin{array}{c}\text { Perubahan } \\
\text { (Ha)/ } \\
\text { Changes }\end{array}$} & \multirow{2}{*}{$\begin{array}{c}\text { Rata-Rata/ } \\
\text { Tahun Average/ } \\
\text { Year (Ha) }\end{array}$} \\
\hline & & $\mathrm{Ha}$ & $\%$ & $\mathrm{Ha}$ & $\%$ & & \\
\hline 1 & Lahan hutan/ Forest land & 17.87 & 1.34 & 16.08 & 1.20 & $(1.80)$ & $(0.20)$ \\
\hline 2 & $\begin{array}{l}\text { Lahan pertanian/ } \\
\text { Agricultural land }\end{array}$ & $1,127.81$ & 84.50 & 704.34 & 52.77 & $(423.46)$ & $(47.05)$ \\
\hline 3 & $\begin{array}{l}\text { Lahan pertanian terlantar/ } \\
\text { Abandoned agricultural land }\end{array}$ & 30.83 & 2.31 & 71.93 & 5.39 & 41.10 & 4.57 \\
\hline 4 & $\begin{array}{l}\text { Lahan Tterbangun/ } \\
\text { Developed land }\end{array}$ & 158.19 & 11.85 & 542.35 & 40.63 & 384.16 & 42.68 \\
\hline & Luas total/Total area $(\mathrm{Ha})$ & $1,334.70$ & 100.00 & $1,334.70$ & 100.00 & & \\
\hline
\end{tabular}

Sumber: Klasifikasi citra landsat ETM+5 tahun 2001 dan 2010./

Source : Landsat ETM +5 image classification in 2001 and 2010. 
Tabel 2 Dinamika Pola Penggunaan Lahan di Wilayah Pesisir Ujung Genteng - Pangumbahan. Kabupaten Sukabumi Tahun 2001 - 2010.

Table 2. The Dynamics of Land Use Pattern in Coastal Area of Ujung Genteng-Pangumbahan, Year 2001-2010.

\begin{tabular}{|c|c|c|c|}
\hline \multirow{2}{*}{ No } & \multicolumn{2}{|c|}{ Penggunaan Lahan/Land Used } & \multirow{2}{*}{ Luas/Area (Ha) } \\
\hline & Tahun/Year 2001 & Tahun/Year 2010 & \\
\hline \multirow[t]{4}{*}{1.} & Lahan hutan/ forest land & Lahan hutan/ Forest land & 16.08 \\
\hline & & Lahan pertanian/Agricultural land & 1.05 \\
\hline & & Lahan terbangun/Developed land & 0.75 \\
\hline & $\begin{array}{l}\text { Lahan hutan total/ } \\
\text { Forest land total }\end{array}$ & & 17.87 \\
\hline \multirow[t]{4}{*}{2.} & $\begin{array}{l}\text { Lahan pertanian/ } \\
\text { Agricultural land }\end{array}$ & $\begin{array}{l}\text { Lahan pertanian/ } \\
\text { Agricultural land }\end{array}$ & 620.31 \\
\hline & & $\begin{array}{l}\text { Lahan pertanian terlantar/ } \\
\text { Abandoned agricultural land }\end{array}$ & 57.12 \\
\hline & & Lahan terbangun/Developed land & 450.38 \\
\hline & $\begin{array}{l}\text { Lahan pertanian total/ } \\
\text { Total of agricultural land }\end{array}$ & & $1,127.81$ \\
\hline \multirow[t]{4}{*}{3.} & $\begin{array}{l}\text { Lahan pertanian terlantar/ } \\
\text { Abandoned agricultural land }\end{array}$ & Lahan pertanian/Agricultural land & 19.46 \\
\hline & & $\begin{array}{l}\text { Lahan pertanian terlantar/ } \\
\text { Abandoned agricultural land }\end{array}$ & 8.29 \\
\hline & & Lahan terbangun/Developed land & 3.07 \\
\hline & $\begin{array}{l}\text { Lahan pertanian terlantar } \\
\text { Total/Total of abandoned } \\
\text { agricultural land }\end{array}$ & & 30.83 \\
\hline \multirow[t]{5}{*}{4.} & $\begin{array}{l}\text { Lahan terbangun/ } \\
\text { Developed land }\end{array}$ & $\begin{array}{l}\text { Lahan pertanian/ } \\
\text { Agricultural land }\end{array}$ & 63.51 \\
\hline & & $\begin{array}{l}\text { Lahan pertanian terlantar/ } \\
\text { Abandoned agricultural land }\end{array}$ & 6.52 \\
\hline & & Lahan Terbangun/Developed land & 88.16 \\
\hline & $\begin{array}{l}\text { Lahan terbangun total/ } \\
\text { total of developed land }\end{array}$ & & 158.19 \\
\hline & Luas total/Total area & & $1,334.70$ \\
\hline
\end{tabular}

Sumber: Hasil analisis citra landsat tahun 2001 dan 2010, diolah./

Source: Results of analysis of Landsat imagery in 2001 and 2010, processed

Sebelum tahun 2010, lahan pertanian terlantar semula merupakan lahan perkebunan kelapa, namun kemudian menjadi semak belukar semenjak tanaman budidaya tersebut ditebang oleh masyarakat. Setiap upaya penghijauan oleh perusahaan tidak pernah berhasil karena dihalangi oleh masyarakat.
Lahan yang mengalami konflik pemilikan ini sebagian besar berada di sekitar pantai. Berdasarkan sejarahnya, lahan ini semula areal berhutan yang diklaim milik negara oleh pemerintah pusat. Namun di tingkat desa, lahan tersebut diklaim sebagai milik desa dan merupakan areal cadangan. Hal 
inilah yang menyebabkan masyarakat setempat dapat membukanya sebagai areal perladangan dan bahkan mengklaim sebagai miliknya karena terdaftar dalam register desa. Namun pada awal tahun 1980an, areal tersebut diklaim pemilikannya oleh sebuah perusahaan swasta dan selanjutnya dimanfaatkan sebagai areal perkebunan kelapa dengan status kepemilikan berupa Hak Guna Usaha Green Belt. Meskipun dalam gugatan anggota masyarakat ke pengadilan dimenangkan, namun kekuatan hukum tersebut tampaknya tidak digubris. Lahan tetap dimiliki dan dikuasai secara privat hingga kini, ditunjukkan dengan pengalihan pemilikan dari perusahaan swasta yang bersengketa dengan masyarakat kepada perusahaan swasta lain. Periode ini juga ditandai oleh perubahan lahan pertanian menjadi lahan terbangun yang signifikan. Sumbernya adalah meningkatnya tekanan kebutuhan lahan untuk pemukiman masyarakat. Tekanan terjadi pada daerah sepanjang pantai Ujung Genteng yang menjadi basis pemukiman masyarakat nelayan dan beberapa dusun di Pangumbahan di sekitar daerah Ciburial yang menjadi basis pemukiman masyarakat petani.

Pada tahun 2010, institusi pengelolaan kawasan konservasi penyu telah mulai diterapkan berdasarkan Peraturan Daerah Kabupaten Sukabumi No. 2 Tahun 2009 Tentang Pelestarian Penyu di Kabupaten Sukabumi dan Peraturan Bupati Sukabumi Nomor 49 Tahun 2010 tanggal 14 Desember 2010 tentang Perubahan Atas Peraturan Bupati Sukabumi Nomor 71 Tahun 2008 tentang Struktur Organisasi dan Tata Kerja Dinas Kelautan dan Perikanan Kabupaten Sukabumi, dengan nomenklatur Unit Pelaksana Teknis Daerah Konservasi Penyu Pangumbahan. Kawasan konservasi penyu yang dikelola adalah seluas 58,43 Ha dengan status Tanah HPL Pemerintah Daerah Kabupaten Sukabumi. Secara administratif terletak di Desa Pangumbahan Kecamatan Ciracap Kabupaten Sukabumi Provinsi Jawa Barat. Berdasarkan rencana pengelolaan kawasan konservasi penyu yang disusun pada tahun 2009-2010, Kawasan Konservasi Penyu Pangumbahan dibagi ke dalam 3 (tiga) zona, yaitu zona inti, zona penyangga dan zona pemanfaatan (Gambar 3).

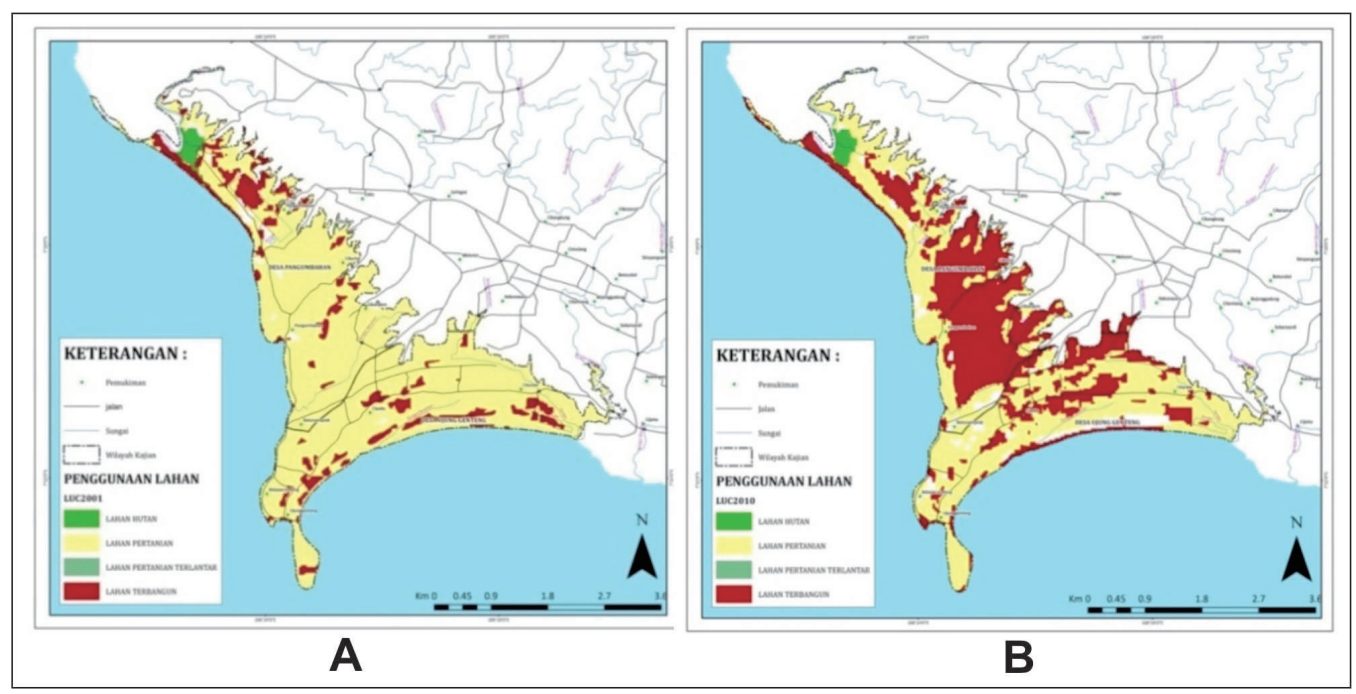

Gambar 1. Pola Penggunaan Lahan Wilayah Pesisir Ujung Genteng - Pangumbahan, Kabupaten Sukabumi Tahun 2001 (A) dan Tahun 2010 (B).

Figure 1. Land Use Patterns of Coastal Areas Ujung Genteng - Pangumbahan, Regency of Sukabumi In 2001 (A) And In 2010 (B). 


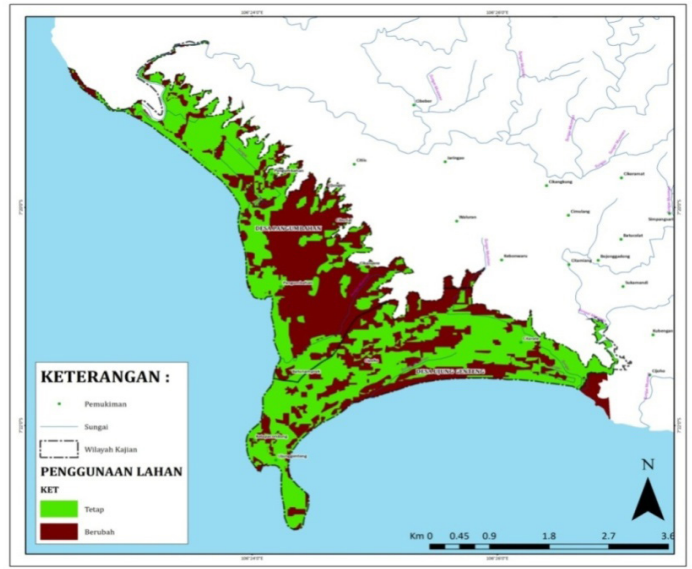

Gambar 2. Pola Perubahan Penggunaan Lahan Wilayah Pesisir Ujung Genteng - Pangumbahan, Kabupaten Sukabumi Tahun 2001-2010.

Figure 2. The Pattern of Changes in Land use of Coastal Areas Ujung Genteng - Pangumbahan, Regency of Sukabumi Years 2001-2010.

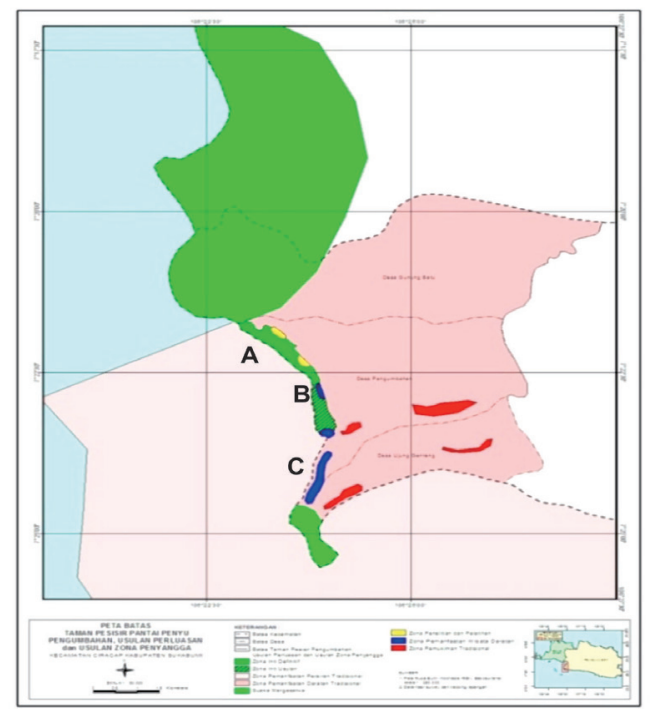

Gambar 3. Rencana Pengelolaan Kawasan Konservasi Penyu Pangumbahan.

Figure 3. Pangumbahan Turtle Conservation Area Management Plan.

Keterangan: $\mathrm{A}=$ Zona Inti, $\mathrm{B}=$ Zona Penyangga, $\mathrm{C}=$ Zona Pemanfaatan Description: $A$ = Core Zone, Buffer Zone $B=, C=$ Use Zone

Pengamatan pada zona penyangga setelah kebijakan konservasi penyu tersebut diterapkan adalah masih terjadinya mekanisme akses ilegal berupa perubahan penggunaan lahan yang terstruktur di sepanjang pantai sekitar wilayah Dusun Pangumbahan dan Dusun Ujung Genteng tersebut. Fenomena ini dapat dibagi kedalam dua fase, yaitu fase pengalihan lahan pertanian terlantar menjadi lahan pertanian dan fase perubahan lahan pertanian menjadi lahan terbangun. 
Masyarakat setempat, merasa bahwa lahan tersebut milik mereka, mematok lahan, menanaminya dengan tanaman palawija seperti umbi-umbian dan menjual kepada masyarakat luar yang kemudian membangun sarana wisata di atasnya. Berdasarkan wawancara mendalam dengan warga Dusun Pangumbahan serta aparat pemerintah pengelola UPTD Konservasi Penyu Pangumbahan, fenomena tersebut disebabkan oleh tingginya permintaan lahan sebagai areal pembangunan fasilitas wisata bahari (losmen atau villa) karena wisatawan yang juga semakin banyak. Jika fenomena ini berlanjut, maka hasil analisis peramalan spasial memproyeksikan seluruh areal pantai di sepanjang Ujung Genteng - Pangumbahan akan tertutup oleh bangunan dan utamanya untuk aktivitas wisata pada tahun 2020 (Gambar 4).

\section{Perubahan dan Pengembangan Institusi Pengelolaan Kawasan Konservasi Penyu yang Efektif}

Berdasarkan hasil analisis spasial serta analisis kualitatif rejim hak kepemilikan dan hak akses terhadap sumberdaya lahan serta konservasi penyu yang melatari perubahan spasial penggunaan sumberdaya lahan tersebut maka kondisi institusi antara sebelum dan setelah kebijakan konservasi penyu hijau diterapkan di wilayah pesisir Ujung Genteng - Pangumbahan ${ }^{6}$ disajikan pada Tabel 4 dan 5.

\section{Tabel 3. Proyeksi Penggunaan Lahan (Hektar) Tanpa Perlakuan Institusi Pengelolaan Kawasan Konservasi Penyu Yang Efektif, Tahun 2015-2020.}

Table 3. Projected Land Use (Acres) Without Treatment of an Effective Turtle Conservation Management Institutions E, Year 2015-2020.

\begin{tabular}{|c|c|c|c|}
\hline \multirow[t]{2}{*}{ No } & \multirow[t]{2}{*}{$\begin{array}{l}\text { Penggunaan Lahan/ } \\
\text { Land Used }\end{array}$} & \multicolumn{2}{|c|}{$\begin{array}{l}\text { Perubahan Luasan Lahan (Ha) Tanpa Institusi Pengelolaan } \\
\text { Kawasan Konservasi yang Efektif/ Changes in Size of Land } \\
\text { (Ha) without an Effective Conservation Area Management } \\
\text { Institutions }\end{array}$} \\
\hline & & Tahun/ Year 2010 & Tahun/Year 2015 - 2020 \\
\hline 1 & Lahan hutan/Forest land & 16.08 & 12.44 \\
\hline 2 & Lahan pertanian/ Agricultural land & 704.34 & 252.06 \\
\hline 3 & $\begin{array}{l}\text { Lahan pertanian terlantar/ } \\
\text { Abandoned agricultural land }\end{array}$ & 71.93 & 0.0 \\
\hline 4 & Lahan terbangun/Developed land & 542.35 & 646.67 \\
\hline 5 & $\begin{array}{l}\text { Potensial lahan terbangun/ } \\
\text { Potential developed land }\end{array}$ & & 423.53 \\
\hline \multicolumn{2}{|c|}{ Luas total (Ha)/Total area (Acres) } & $1,334.70$ & $1,334.70$ \\
\hline
\end{tabular}

\footnotetext{
${ }^{6}$ Institusi adalah aturan main dan aturan penegakkannya di dalam sebuah masyarakat (North 1991). North (1991) menambahkan, institusi dapat berbentuk aturan formal seperti hukum dan konstitusi ataupun aturan informal seperti konvensi dan norma, yang seluruhnya merupakan produk dari interaksi antar manusia. Perubahan institusi (institutional change) akan menyebabkan perubahan aktor, karena adanya perubahan pada tujuan dan pilihan yang ditetapkan oleh institusi tersebut. Kingston dan Caballero (2009) menyatakan bahwa hal terpenting dalam mengkaji perubahan institusi terletak pada 3 (tiga) hal, yaitu: (a) Penyebab perubahan. Dalam hal ini pertanyaan berkisar pada sumber perubahan, apakah berasal dari dalam atau luar komunitas, dan pengaruh mana yang lebih penting dalam jangka pendek dan jangka panjang; (b) Proses perubahan. Dalam hal ini pertanyaan berkisar pada proses perubahan yang terjadi, apakah terjadi secara disengaja atau tidak disengaja, terjadi tiba-tiba atau bertahap atau merupakan hasil sebuah upaya kooperatif atau konflik. Pertanyaan penting lainnya adalah: faktor yang menyebabkan institusi bisa bertahan, peran proses pengambilan keputusan, peran latar belakang dan cara berpikir (bounded-rationality) dan interaksi antara aturan formal dan informal; (c) Hasil perubahan. Dalam hal ini pertanyaan berkisar pada bentuk lingkungan seperti apa institusi yang efektif cenderung muncul. Jika ada banyak pilihan keseimbangan baru, hasil yang manakah kiranya akan dipilih dan seberapa jauh hal-hal yang terkait dengan bounded-rationality para aktor di dalam penentuan hasil perubahan institusi tersebut.
} 


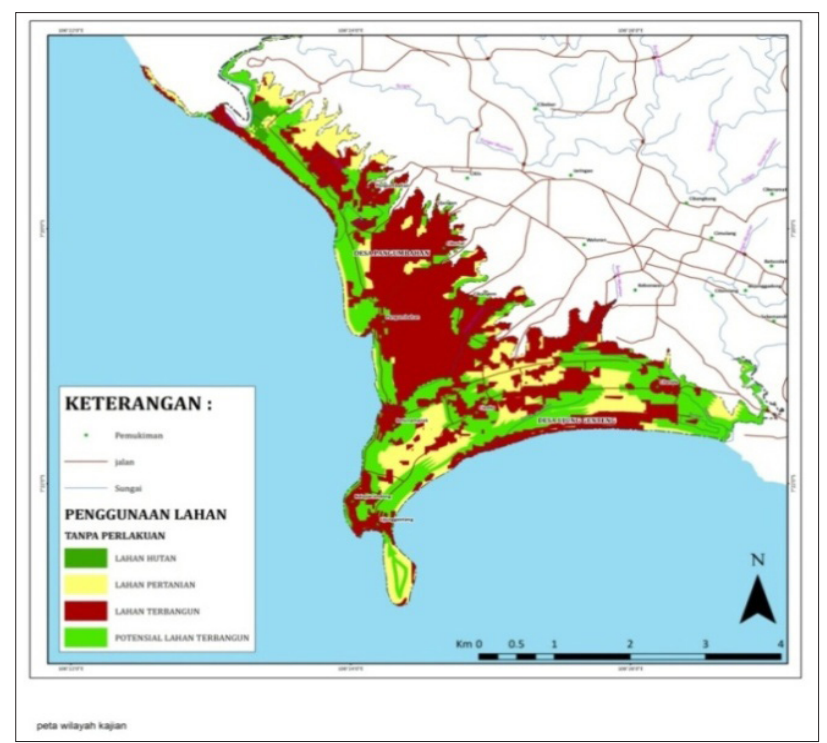

Gambar 4. Proyeksi Penggunaan Lahan Tanpa Institusi Pengelolaan Kawasan Konservasi Yang Efektif Pada Tahun 2020.

Figure 4. Projected Land Use Without an Effective Management of Protected Areas Institution by 2020.

Tabel 4. Kondisi Institusi Pengelolaan Sumberdaya Lahan di Pesisir Ujung GentengPangumbahan Sukabumi Sebelum Kebijakan Konservasi Penyu Diterapkan.

Table 4. The Condition of Land Resources Management Institutions in the Coastal of Ujung Genteng - Pangumbahan Sukabumi Before the Application of Turtle Conservation Policy.

\begin{tabular}{|c|c|c|c|}
\hline \multirow[b]{2}{*}{ No. } & \multirow{2}{*}{$\begin{array}{l}\text { Tipologi Hak Penge- } \\
\text { Iolaan Sumberdaya } \\
\text { Lahan/ Typology- } \\
\text { Right Management } \\
\text { Of Land Resources }\end{array}$} & \multicolumn{2}{|c|}{ Komponen Institusi/Institution Component } \\
\hline & & $\begin{array}{l}\text { Aturan main/ } \\
\text { Rules Of The Game }\end{array}$ & Aktor/Actors \\
\hline \multirow[t]{2}{*}{1.} & $\begin{array}{l}\text { Hak kepemilikan/ } \\
\text { Property Rights }\end{array}$ & $\begin{array}{l}\text { Formal, kepentingan ekonomi/ } \\
\text { Formal, economic interests }\end{array}$ & $\begin{array}{l}\text { Luar masyarakat (perusahaan perkebunan), } \\
\text { pengaruh jangka panjang/ Outside the } \\
\text { community (plantation), the long-term effects }\end{array}$ \\
\hline & & $\begin{array}{l}\text { Informal, kepentingan ekonomi/ } \\
\text { Informal, economic interests }\end{array}$ & $\begin{array}{l}\text { Masyarakat, pengaruh jangka panjang/ } \\
\text { Communities, the long-term effects }\end{array}$ \\
\hline \multirow[t]{2}{*}{2.} & $\begin{array}{l}\text { Hak pemeliharaan } \\
\text { akses/ Maintenance } \\
\text { of access rights }\end{array}$ & $\begin{array}{l}\text { Formal, kepentingan ekonomi/ } \\
\text { Formal, economic interests }\end{array}$ & $\begin{array}{l}\text { Luar masyarakat (perusahaan perkebunan), } \\
\text { pengaruh jangka pendek/ Outside the } \\
\text { community (plantation), the short-term effects }\end{array}$ \\
\hline & & $\begin{array}{l}\text { Informal, kepentingan ekonomi/ } \\
\text { Informal, economic interests }\end{array}$ & $\begin{array}{l}\text { Masyarakat, pengaruh jangka pendek/ } \\
\text { Communities, the short-term effects }\end{array}$ \\
\hline \multirow[t]{2}{*}{3.} & $\begin{array}{l}\text { Hak pengaturan } \\
\text { akses/ Rights of } \\
\text { access arrangements }\end{array}$ & $\begin{array}{l}\text { Formal, kepentingan ekonomi/ } \\
\text { Formal, economic interests }\end{array}$ & $\begin{array}{l}\text { Pemerintah (kantor pertanahan), pengaruh } \\
\text { jangka panjang/ Government (land office), } t \\
\text { he long-term effects }\end{array}$ \\
\hline & & $\begin{array}{l}\text { Informal, kepentingan ekonomi/ } \\
\text { Informal, economic interests }\end{array}$ & $\begin{array}{l}\text { Masyarakat, pengaruh jangka panjang/ } \\
\text { Community, the long-term effects }\end{array}$ \\
\hline
\end{tabular}


Tabel 5. Kondisi Institusi Pengelolaan Sumberdaya Lahan di Pesisir Ujung Genteng Pangumbahan Sukabumi Setelah Kebijakan Konservasi Penyu Diterapkan.

Table 5. The Condition of Land Resources Management Institutions in the Coastal of Ujung Genteng - Pangumbahan Sukabumi After the Application of Turtle Conservation Policy.

\section{Komponen Institusi/Institution Component}

Tipologi Hak Pengelolaan Sumberdaya

No. Lahan/ Typology Right Management Of Land Resources

\section{Aturan Main/ Rules Of The Game}

Aktor/Actors
1. Hak kepemilikan/ Property Rights
2. Hak pemeliharaan akses/Maintenance of access rights
Formal, kepentingan ekonomi/ Formal, economic interests

Informal, kepentingan ekonomi/ Informal, economic interests
Informal, pemenuhan kepentingan ekonomi/ Informal, the fulfillment of the economic interests
Luar masyarakat (perusahaan perkebunan), pengaruh jangka pendek/ Outside the community (plantation), the short-term effects

Luar masyarakat (investor penyedia jasa wisata), pengaruh jangka panjang/ Outside the community (investor tourism services provider), long-term effects

Masyarakat, pengaruh jangka panjang/Communities, the long-term effects

Luar masyarakat (investor penyedia jasa wisata), pengaruh jangka pendek/ Outside The Community (investor tourism services provider), short-term effects

Masyarakat (penyedia tenaga jasa wisata), pengaruh jangkapendek/ Community(tourism services provider), short-term effects

Pemerintah (kantor pertanahan), pengaruh jangka panjang / Government (land office), the long-term effects Informal, pemenuhan kepentingan Masyarakat, pengaruh jangka
ekonomi/ Informal, the fulfillment of the panjang /Communities, the economic interests

Sumber: Data primer, diolah/Source: Primary data, processed.

Agar institusi pengelolaan kawasan konservasi penyu dapat efektif maka dibutuhkan aturan main yang dapat mendayagunakan tanah terlantar di sekitar kawasan konservasi, yaitu lahan dengan status HGU sepanjang pantai Pangumbahan, sesuai tujuan konservasi, yaitu menjamin kelestarian populasi penyu dan pantai peneluran sebagai habitatnya serta menjamin keberlanjutan sumber penghidupan masyarakat. Secara prosedural formal, lahan tersebut perlu dialihstatuskan sebagai tanah negara berdasarkan Peraturan 
Pemerintah Republik Indonesia No.11 Tahun 2010 tentang Penertiban dan Pendayagunaan Tanah Terlantar. Setelah status berubah, negara (pemerintah) mengatur pendayagunaannya bersama masyarakat setempat dengan tujuan membangun ekowisata konservasi penyu yang pengelolaannya berbasis pada masyarakat setempat. Lahan tidak dapat diperjualbelikan dan masyarakat luar dibatasi hanya sebatas menikmati manfaatnya sebagai wisatawan. Dinas Kelautan dan Perikanan serta Dinas Pariwisata bekerja sama dalam meningkatkan kapasitas masyarakat setempat, baik secara individu maupun kelompok sehingga dapat meningkatkan potensi manfaat sumberdaya melalui aktivitas penyediaan jasa wisata (pemandu, penyedia kerajinan tanda mata). Pemilihan ekowisata berbasis konservasi penyu dilatarbelakangi oleh prinsip kehati-hatian agar pemanfaatan sumberdaya alam tidak melebihi kapasitas daya dukung lingkungannya. Institusi pengelolaan kawasan konservasi penyu yang efektif sebagaimana dimaksud berikut komponennya disajikan dalam Tabel 6.

Tabel 6. Perubahan Institusi Pengelolaan Sumberdaya Lahan di Pesisir Ujung Genteng Pangumbahan Sukabumi yang Mendukung Pencapaian Tujuan Kebijakan Konservasi Penyu (Pengembangan Intitusi yang Efektif).

Table 6. Changes In Land Resource Management Institutions in the Coastal of Ujung GentengPangumbahan Sukabumi That Supports the Achievement of Policy Turtle Conservation Objectives (The Development of Effective Institutions).

\begin{tabular}{|c|c|c|c|}
\hline \multirow{2}{*}{ No. } & \multirow{2}{*}{$\begin{array}{c}\text { Tipologi Hak Pengelolaan } \\
\text { Sumberdaya Lahan/ Typology } \\
\text { Right Management of Land } \\
\text { Resources }\end{array}$} & \multicolumn{2}{|c|}{ Komponen Institusi/Institution Component } \\
\hline & & $\begin{array}{l}\text { Aturan main/ } \\
\text { Rules of The Game }\end{array}$ & Aktor/Actors \\
\hline \multirow[t]{3}{*}{1.} & $\begin{array}{l}\text { Hak kepemilikan/ } \\
\text { Property Rights }\end{array}$ & $\begin{array}{l}\text { Formal, pemenuhan kepentingan } \\
\text { ekonomi/ Formal, the fulfillment of } \\
\text { the economic interests }\end{array}$ & $\begin{array}{l}\text { Masyarakat, pengaruh jangka panjang/ } \\
\text { Communities, the long-term effects }\end{array}$ \\
\hline & & $\begin{array}{l}\text { Formal, pemenuhan kepentingan } \\
\text { sosial/ Formal, the fulfillment of the } \\
\text { social interests }\end{array}$ & $\begin{array}{l}\text { Masyarakat luar (wisatawan), peng- } \\
\text { aruh jangka panjang/ Outside the } \\
\text { community (tourists), } \\
\text { long-term effects }\end{array}$ \\
\hline & & $\begin{array}{l}\text { Formal, pemenuhan kepentingan } \\
\text { ekologi/ Formal, the fulfillment of the } \\
\text { ecology interests }\end{array}$ & $\begin{array}{l}\text { Pemerintah (zona inti) dan } \\
\text { Masyarakat (zona penyangga)/ } \\
\text { Government } \\
\text { (core zone) and Community } \\
\text { (buffer zone) }\end{array}$ \\
\hline 2. & $\begin{array}{l}\text { Hak pemeliharaan akses/ } \\
\text { Maintenance of access rights }\end{array}$ & $\begin{array}{l}\text { Formal, pemenuhan kepentingan } \\
\text { ekonomi/ Formal, the fulfillment of } \\
\text { the economic interests }\end{array}$ & $\begin{array}{l}\text { Luar masyarakat (investor penyedia } \\
\text { jasa wisata), pengaruh jangka } \\
\text { pendek/ Outside The Community } \\
\text { (investor tourism services } \\
\text { provider), short-term effects }\end{array}$ \\
\hline 3. & $\begin{array}{l}\text { Hak pengaturan akses/ } \\
\text { Rights of access arrangements }\end{array}$ & $\begin{array}{l}\text { Formal, pemenuhan kepentingan } \\
\text { ekonomi, sosial dan ekologi/ Formal, } \\
\text { the fulfillment of the economic, social } \\
\text { and ecology interests }\end{array}$ & $\begin{array}{l}\text { Pemerintah (kementerian kelautan } \\
\text { dan perikanan, badan pertanahan } \\
\text { nasional, pemerintah daerah) dan } \\
\text { masyarakat, pengaruh jangka panjang } \\
\text { / The government (ministry of marine } \\
\text { affairs and } \\
\text { fisheries, national land agency, local } \\
\text { government) and } \\
\text { community, the long-term effects }\end{array}$ \\
\hline
\end{tabular}




\section{KESIMPULAN DAN IMPLIKASI KEBIJAKAN}

Institusi pengelolaan kawasan konservasi penyu yang diterapkan sejak tahun 2010 belum efektif. Masih terdapat mekanisme ilegal penggunaan sumberdaya lahan yang tidak selaras dengan tujuan konservasi penyu berupa pembagunan sarana wisata di lahan terlantar di sepanjang pantai Pangumbahan. Ketidakefektifan institusi disebabkan belum adanya aturan yang dapat menjamin kepemilikan dan selanjutnya pendayagunaan sumberdaya lahan di wilayah pesisir tersebut yang selaras dengan tujuan konservasi.

Institusi pengelolaan kawasan konservasi penyu yang efektif membutuhkan koordinasi dan kerjasama antara pemerintah, mulai dari tingkat pusat hingga tingkat desa serta masyarakat pesisir Ujung Genteng - Pangumbahan itu sendiri. Dibutuhkan pendayagunaan lahan terlantar, yang secara prosedural wewenangnya berada di Badan Pertanahan Nasional. Pendayagunaannya diatur oleh pemerintah pusat dan daerah yang menangani bidang teknis (Kementerian Kelautan dan Perikanan serta dinas-dinas yang secara teknis membidangi Kelautan dan Perikanan, Pariwisata di Kabupaten Sukabumi) dengan melibatkan secara aktif masyarakat setempat terkait dengan pengembangan ekowisata konservasi penyu berbasis masyarakat.

\section{DAFTAR PUSTAKA}

Abarkeli S. 2001. A Critique of Development and Conservation Policies in Environmentally Sensitive Regions in Brazil. Geoforum 32: 551-565.

Anonim. 2004. The IUCN Red List of Threatened Species: Green Turtle (Chelonia mydas). Gland: [IUCN] The World Conservation Union.

Emzir. 2010. Metodologi Penelitian Kualitatif: Analisis Data. PT RajaGrafindo Persada. Jakarta.

Fraze,r N.B. 2003. Concerning Those Things Which We Ought to Have Done: Reflections on the Future of Sea Turtle Research. Marine Turtle Newsletter 100:5-8.

Gerber, J.D. P. Knoepfel, S. Nahrath and F Varone. 2009. Institutional Resources Regimes: Towards sustainability trough the combination of property rights theory and policy analysis. Ecological Economics 698: 798-809.

Kingston, C. and G, Caballero. 2008. Comparing Theories of Institutional Change. Diunduh dari https://www3.amherst. edu/ cgkingston/diakses tanggal 21 September 2011.

North, D.C. 1991. Institutions. The Journal of Economic Perspectives, 5 (1): 97-112.

Ribbot, J.C, N.L Peluso. 2003. A Theory of Access. Rural Sociology 68 (2): 153-181.

Scott, W.R. 2001. Institutions and Organization. Second Edition. California, Sage. 